\title{
Early Learning Experiences and Teacher-Efficacy As Predictors of Pupils'Competencies in Early Primary School Grades in Rural Kenya
}

\author{
Ong'ang'a Hudson Ouko
}

\begin{abstract}
Pre-primary school learning experiences lays a strong foundation for pupils' later academic progression and achievement. The experiences equip learners with the requisite competencies and abilities for formal and life-long learning including basic literacy and numeracy skills. Premised on this commonality, the purpose of this study was to establish pupils' academic achievement in literacy and numeracy on entry to standard one and whether pre-primary school learning experiences and teachers' level self-efficacy predicted pupil's literacy and numeracy achievement. The study also investigated pre-primary school learning experiences and teachers' self-efficacy's predictive value of standard one pupils' literacy and numeracy achievement. Free primary school in Kenya is mandatory for six year olds irrespective of their backgrounds. Pre-primary school education is therefore not a requirement for joining primary one (Standard one) class. In a typical standard one class in Kenya, one would expect pupils with unequal pre-primary school learning experiences. Teacher's self-efficacy equally could influence pupils' academic achievement. Two theories guided this study; Albert Bandura's self-efficacy theory (1982) and the Ecological Systems theory by Urie Bronfenbrenner (1979). Ex post facto research design was used to guide the study. Variables of the study included pre-primary school experiences, gender, teachers' self-efficacy and type of school. The study was conducted in Gucha District of Kisii County, Kenya. The target population was both public and private primary schools in the District. All standard one pupils and their teachers of the sample schools participated. Purposive and stratified random sampling techniques were employed. Eight (8) primary schools formed the sample of the study. A total of six public and two private schools formed the study sample. This was comprised of $16 \%$ of the population. The total sample was 154 pupils and eight (8) teachers. Descriptive and inferential techniques were employed to analyze data. Statistical Package for Social Sciences (SPSS) programme was used to analyze data. Means and percentages were calculated and inferential statistics involved Analysis of Variance (ANOVA). ANOVA was used to test, H01, H02, $\mathrm{HO3}$ and $\mathrm{HO4}$ while $\mathrm{HO5}$ was analyzed using multiple regression. A $P \leq 0.05$ level of significance was accepted. The findings of the study revealed that pre-primary school learning experiences together with teachers' level of self-efficacy significantly predicted pupils' literacy and numeracy achievement. One of the recommendations based on the study findings was that policy makers at both central and county governments should invest substantial resources in pre-primary school programmes in order to improve academic outcomes in primary school level to avoid investing too much too late.
\end{abstract}

Index Terms - Early learning experiences, Teacher-efficacy, Competences, Predictors.

Ong'ang'a Hudson Ouko, Lecturer, Department of Early Childhood

\section{INTRODUCTION}

Background of the Study

Literacy and numeracy are basic skills learners needed for smooth transition from on grade to the next. Therefore thereof is pertinent in laying a firm foundation for young children as they enter formal school learning. It is argued that proficiency in reading, writing and mathematics are major indicators of social wellbeing for all people, providing not only the skills for meaningful interactions with the world, but also the foundations for success in education and beyond school (Ouko, 2015; COAG, 2008).

Quality pre-primary school education can greatly facilitate and promote the achievement of global development goals including the MDGs and SDGs.

Pursuant to the millennium development goal (MDG) of universal, accessible and affordable quality education, basic education remains a priority in Kenya. This is however true with primary and secondary education.

Since independence in 1963, Kenya has made remarkable strides towards improved access to education at all levels. Enrolment at the primary level rose from 6.1million in 2002 to slightly above $7.6 \mathrm{~m}$ in 2005 (MoEST, 2008). Research has shown that the early years of an individual are a critical period, where the path-way of the individual's lifetime social, emotional and intellectual outcomes are founded. This therefore underscores the need for quality, accessible and universal and free pre-primary school education programmes as an integral component in promoting competence development and holistic growth and development of children (Harrison, Goldfeld, Metcalfe and Moore, 2012; Ouko 2015). Pre-primary school experiences can help lay a firm foundation of learning capabilities and successesin later schooling. These experiences equip the learner with the necessary requisite early literacy and numeracy skills and competencies that promote the overall academic achievement in later grades.

Studies have shown that early childhood years (3-8) form the formative stage characterized by critical growth and development milestones (Barnet, 1995; Myers and Lander, 1989; Randerson, 2008). Children's cognitive development is at its best at this age since by the eighth birth day, an individual's brain development would have attained up to $80 \%$ capacity.

Children who successfully complete their pre-primary school grades before joining formal schooling, often cope 


\section{Early Learning Experiences and Teacher-Efficacy As Predictors Of Pupils'Competencies in Early Primary School Grades in Rural Kenya}

with primary school curriculum with ease (MoE, 2006; Myers and Lander, 1989; UNESCO, 2005). This is even more salient with children from disadvantaged socio-economic backgrounds or simply children at risk (Harrison et al, 2012). Notwithstanding the benefits associated with quality pre-primary school education, the same has not been compulsory and free in Kenya. In Kenya the gross enrolment rate at pre-primary school level is estimated at $35 \%$ (UNESCO, 2005). This means that most eligible pre-primary school pupils are still not enrolled or simply join grade one without the necessary experiences and readiness to manage primary literacy and numeracy tasks (Ouko, 2015). This study investigated pre-primary school experiences' predictive value on standard one pupils' academic achievement in literacy and numeracy. Further the study investigated teacher-efficacy's effect on learners' literacy and numeracy competence acquisition.

In Kenya, performance in local and national examinations have remained low in languages and mathematics over time now. This situation can be attributed to low levels of preparedness of the learners before joining school (KNEC, 2016). This study investigated the influence of pre-primary school experiences and teacher-efficacy on pupils' learning literacy and numeracy out-comes at primary grade one.

\section{Statement of the Problem}

The theory and practice in early childhood programmes globally are far from being homogeneous in nature. Although there is glaring positive long-term impact of quality pre-primary school experiences on the overall academic achievement of the children there are no deliberate strategies in Kenya geared towards ensuring quality of pre-school education( ). This explains why pre-primary school education in Kenya is everybody's responsibility (partnership). There is enough evidence on the direct link between pre-primary school educational experiences and academic performance in primary schools (Taiwo and Tyolo, 2002) available evidence from the "head-start" programmes in the USA, attests to this argument, where children who went through the head-start programme out-performed their counterparts in academic progression and achievement (Barnett, 1995). In Kenya, however more resources and emphasis are directed to primary school and higher levels of education without rather than early childhood programmes. A lot of resources are directed towards pupils who are about to take national examination rather than laying a good foundation in the learners in preparation for later learning. This results in what would be referred to as "too much, too late" (Ouko, 2015). The question that arises is whether pupils joining primary grade one. This study therefore investigated pre-primary school learning experiences and teacher-efficacy as predictors of pupils' literacy and numeracy achievement in Kenya.

\section{PURPOSE OF THE STUDY}

This study aimed at establishing the extent to which pre-primary early experiences and teacher-efficacy predict pupils' literacy and numeracy achievement.

\section{Research Questions}

This study sought to answer the following research questions;

i) Does pre-primary school learning experiences predict pupils' early literacy and numeracy achievement?

ii) To what extent does teacher-efficacy predict pupils' achievement in literacy and numeracy?

\section{Theoretical Framework}

This study was guided by two theories; Ecological Systems TheorybyUrie Bronfenbrenner (1979). Ecological Systems Theoryexplains exclusively on the influence of one's immediate environment on the individual's growth and development suiting only on pre-primary school experiences.

The ecological systems theory is sometimes referred to as development in context or human ecology theory (Kail, and Cavanaugh, 2010). The theory explains the phenomenon of child development in the context of environmental input. That is, how the ecology (environment) affects the child's growth and development. The theory postulates five environmental (ecological) systems with which the child interacts and which helps in shaping the growth and development outcomes of the child. According to this theory, there are five ecological subsystems that are interconnected and interplay to influence the individual's growth and development.

At early childhood level, two systems would apply; microsystem which refers to immediate institutions and groups that are immediate to the child; themeso-systems which are interconnected with the microsystems interactions including family, school and peers.

Human ecology or "environments"; from the family to economic and political structures have come to be viewed as part of the life course from childhood through adulthood. The theory explains that individuals move through a series of life transitions, all of which necessitate environmental support and coping skills. The individual's environment and the ecological model can be a good basis of understanding growth and development of an individual (Santrock, 2007). Based on this model, it is believed that the early interactions of the child's genes and biological personality traits with the environmental experiences would affect significantly the way a child grows and develops. Consequently, a child's early experiences have a major influence on the child's development. This theory was selected because it relates well with the current study which focuses on pre-primary school learning experiences as a predictor of pupils' academic achievement in literacy and numeracy.

\section{RELEVANT LITERATURE}

Achievement in literacy can be a good indicator of a learner's future learning achievement in education. In school, children's success is measured by literacy competencies or how well they meet the learning objectives. Academic achievement is the outcome of education or the extent to which learners, teachers or institutions have achieved their educational goals (Fabian, 2007). The major indicator of academic performance in education is learners' overall scores in language and mathematics. In early years education learners' literacy and numeracy competencies are therefore 
critical.

According to UNICEF (2007), academic achievement at pre-primary school and primary I, II\& III can predict individual learners' academic success in the subsequent levels of education. Gay, 1981; Felner, Jackson, Kasak, Mulhall, Brand and Flowers, 1997)), alludes to various factors that can be attributed to the level and quality of learners' literacy achievement including but not limited to individual, family, school, and community factors. This study sought to investigate early years' experience and teacher-efficacy as predictors of pupils' achievement in literacy and numeracy and achievement in pupils' literacy and numeracy.

Green \& Riddle (2012; Randerson, 2008), posts that there are tangible and positive long-term benefits of pre-primary school experiences which include building substantial cognitive, basic literacy, numeracy and problem-solving skills. This underscores the important role pre-primary school can play in later and lifelong learning.

Barnett (2008)'s study provides further revelation on lasting effects of pre-primary school effects. A review of studies aimed at understanding the short and long-term effects on learners' academic progress and achievement. Results from this study further showed that pre-primary school programmes have positive effects on children's learning outcomes and development, all be it the effects varied in type and persistence from by type of programme. It was further established that well-designed preschool education programmes produced long-term improvement in school success including higher educational attainment. Previous studies focused on the overall effects of pre-primary experiences while the current study investigated standard one pupils' literacy and numeracy achievement. The strongest evidence however was that economically disadvantaged children reaped more long-term benefits from preschool programmes (Taiwo\&Tyolo, 2002).

A stud by Marcon (1999) in the United States established that; early childhood education was positively related to primary school academic achievement and beyond particularly in reading. The study further revealed that early childhood education experiences contributed to higher performances in specific skill areas such as reading and mathematics. The current study investigated whether pre-primary school experiences and teachers- efficacy predict pupils' achievement in literacy and numeracy.

Grossman (1997) conducted a study on the effectiveness of a pre-first grade program on later academic achievement. The purpose of the study was to investigate the academic effectiveness of a pre-first grade program in a sub-urban upper class school system. Children who spent an extra year in pre-first grade program were matched with youngsters who proceeded directly to first grade based on gender and date of birth. A significant difference in academic achievement was recorded in numeracy and no significance difference in literacy. This study investigated whether there was a difference in literacy and numeracy achievement between children with pre-primary school learning experiences and those who join primary school without adequate pre-primary school learning experiences. The study further investigated whether teachers' efficacy levels influenced learners' learning outcomes in literacy and numeracy competencies.

In Nigeria, Osakwe (2009) investigated the effects of early childhood education experiences on the academic performance of primary school children. The findings revealed that there was a significant difference between pupils who had pre-primary school education experiences and those without such experiences in their academic performance, cognitive ability, social skills and motor skills. Academic performance in Kenya is a concern of various stakeholders particularly due to low academic achievement in science related subjects. The current investigated pre-primary school and teacher-efficacy as predictors of academic achievement.

On teacher-efficacy, studies have shown that teachers' positive and high self-efficacy have positive impact on students' academic achievements and motivations (Caprara, Barbaranell, Steca and Malone, 2006; Ozerkan, 2007; Midgley, Feldlaufer and Eccles, 1989; Multon\& Brown 1999; Pajares, 2002). It is argued therefore that teachers' self -efficacy may in turn contribute positively or negatively to students' sense of efficacy and their efforts in facing difficulties (Ross, 1998). Teachers' efficacy is therefore a positive and significant predictor of pupils' vocabulary gains only within the context of high quality emotionally supportive classrooms (Guo, Piasta, Justice and Kaderavek, 2010).

Goddard, Hoy and Woolfolk (2011) argue that self-efficacy is a good indicator or predictor of teaching effectiveness. If a teacher feels confident that he or she can teach all students, regardless of their race, ethnicity, learning ability, or background, and achieve their objective, then that teacher would be described as being highly efficacious. Research has shown that teachers who are highly efficacious have the ability to show higher levels of effort and are resilient in their efforts, even in difficult and challenging situations (Goddard, Hoy and Woolfolk, 2011; Barnett,1995). They further define teacher self-efficacy as a teacher's "judgment of his or her capabilities to bring about desired outcomes of student engagement and learning, even among those students who may be difficult or unmotivated.

Another dimension of teacher efficacy is internal efficacy, which is concerned with the degree to which a teacher believes he or she has the influence, will, and ability to affect students learning; or whether student learning is the end result of forces put in place outside the classroom setting. The internal efficacy view takes into consideration the personality, confidence level, and teaching strategies embraced by the teacher.

Teachers with internal efficacy believe strongly in their ability to teach all students regardless of race, gender, ethnicity, or social background, and that they can help them to be successful academically. On the other hand, external efficacy is the view that a student's background, family status, and social upbringing are key factors that influence student learning in the classroom (Barnett, 1995).

Few studies have however been conducted in Kenya focusing on teachers-efficacy's influence on learners' learning outcomes. Mwoma, Liboro and Mugo (2013), 


\section{Early Learning Experiences and Teacher-Efficacy As Predictors Of Pupils'Competencies in Early Primary School Grades in Rural Kenya}

investigated the quality of teachers teaching lower primary classes with a focus of standard two in three provinces (central, lift valley and western). The study revealed that most teachers teaching lower primary had limited access to training and in service programmes necessary for quality teaching and therefore lacked in crucial knowledge and physical resources for effective teaching. This study in away was about the efficacy teachers had with their work of teaching children. The study did not investigate teacher-efficacy and pupils' academic achievement which the current study addressed.

\section{RESEARCh DESIGN AND METHODOLOGY}

Ex post facto research design was employed. The researcher adopted descriptive survey method to investigate the effects of pre-school experiences and teacher-efficacy's influence on literacy and numeracy competencies among first graders in primary education. In this study pupils' literacy and numeracy mean scores in end of term evaluation was utilized to determine the extent to which pre-primary school learning experiences and teachers' level of self-efficacy influenced pupils' achievement in literacy and numeracy.

Kothari (2004) explains that descriptive surveys method in social sciences aims at fact-finding of the state of affairs as they exist at present by collecting, collating and analyzing available evidence in order to make informed inferences. Descriptive survey design often involves collecting, processing and analyzing large data in order to make decisions on a specific phenomenon (Orodho, 2009; Robson, 2011). In this study the researcher could not envisage actual control of the independent variables, since their effects had already been felt hence Ex post facto design. Best (1992) explains that an ex post facto design is used when the researcher does not envisage actual control of the independent variables whose effects have already been felt. The design envisages a systematic approach in collecting, collating and analyzing data in a bid to make informed inferences and conclusions regarding phenomena. The design was selected because it was considered appropriate since this study employed a systematic approach in collecting, collating and analyzing data in order to draw informed inferences and conclusions. The current study yielded large data particularly on achievement in literacy, numeracy, pre-primary school learning experiences and teachers' level of self-efficacy and drew conclusions based on the results thereof.

Purposive sampling and stratified random sampling techniques were used in drawing the study sample. A $10 \%$ sample was used.

\section{FINDINGS OF THE STUDY}

\section{Demographic Information}

The demographic information of the population is illustrated in the table below. Category of schools were either public pre-primary schools or private pre-primary schools. Private pre-primary schools constituted those standing alone and those attached to privately managed pre-primary schools while public pre-primary schools were all attached to public schools.

\begin{tabular}{|c|c|c|c|}
\hline Category & F & N & \% \\
\hline $\begin{array}{c}\text { Public } \\
\text { primary } \\
\text { schools }\end{array}$ & 6 & 120 & 78 \\
\hline $\begin{array}{c}\text { Private } \\
\text { primary } \\
\text { schools }\end{array}$ & 2 & 34 & 22 \\
\hline Total & 8 & 154 & 100 \\
\hline
\end{tabular}

\section{Pupils' Demographic Information Table}

From the above table, majority (78\%) of the pupils who participated in this study were from public primary schools while $22 \%$ of the pupils were from private primary schools. This was because few private primary schools were registered with the Ministry of Education science and technology (MoEST). Only registered schools were included in the study sample.

\section{iii) Teachers' Demographic Information}

The demographics of the distribution of public and private pre-primary schools is illustrated as under.

\begin{tabular}{|l|c|c|}
\hline Category & $\mathbf{N}$ & $\boldsymbol{\%}$ \\
\hline Public & 6 & 75 \\
\hline Private & 2 & 25 \\
\hline Total & 8 & 100 \\
\hline
\end{tabular}

\section{Teachers per Type of School}

The above table shows that majority of the sample teachers (75\%) was from public pre-primary schools. This implies that there were more public pre-primary school in the study area.

\section{Findings of the Study}

This study sought to answer the following research questions;

i. Does pre-primary school learning experiences predict pupils' early literacy and numeracy achievement?

ii. To what extent does teacher-efficacy predict pupils' achievement in literacy and numeracy?

\begin{tabular}{|c|l|l|}
\hline Pupils & Literacy & Numeracy \\
\hline $\begin{array}{c}\text { Attended } \\
\text { pre-primary }\end{array}$ & 78.00 & 71.06 \\
\hline $\begin{array}{c}\text { Did not } \\
\text { attend }\end{array}$ & 67.37 & 70.00 \\
\hline
\end{tabular}

iv) Pupils 'Achievement in Literacy and Numeracy

Pupils' mean scores in both literacy and numeracy were obtained, collated and mean scores calculated to find the general literacy and numeracy achievement. The following table presents the results on pupils' academic achievement in literacy and numeracy. 


\begin{tabular}{|c|c|c|}
\hline N=154. & $\begin{array}{c}\text { Literacy } \\
\text { score }\end{array}$ & $\begin{array}{c}\text { Numeracy } \\
\text { Score }\end{array}$ \\
\hline Mean & 68.4 & 71.8 \\
\hline Median & 70.0 & 74.0 \\
\hline Mode & 64.0 & 88.0 \\
\hline $\begin{array}{c}\text { Std. } \\
\text { Deviation }\end{array}$ & 19.2 & 18.9 \\
\hline Minimum & 10.0 & 12.0 \\
\hline Maximum & 100.0 & 100.0 \\
\hline
\end{tabular}

It is clear that scores of the pupils who had attended pre-primary school programme were $78 \%$ in literacy and $71 \%$ in numeracy respectively while those who did not attend pre-primary school were $67.37 \%$ and $70 \%$ respectively. It emerged that pupils who had attended pre-primary school posted higher scores in both numeracy and literacy compared with those who did not attend pre-primary school. To establish whether the difference in pupils' achievement in literacy and numeracy between those who attended pre-primary school and those who did not was significant the following ANOVA was run and the results are presented in the table below.

\section{Achievement in Literacy and Numeracy}

The tables above shows that pupils' mean score in literacy was 68.4 while the mean score in numeracy was 71.8 . The results show that thepupils' performed better in numeracy compared to literacy. This can be attributed to the fact that numeracy tasks may well involve numerals that are easily understood than words that require interpretation.Early studies have either addressed gender differences or differences based on type of schools in the performance of mathematics, sciences and social studies (Chege, F.,Lukoye, F, Nyambura, S and Guantai, H. K. 2012; Kiptum J K, Rono P K., Too J K.,. Bii, B.K, Too J, 2013). These studies also focused on upper primary or high school students. The current study investigated literacy and numeracy achievement of primary grade one pupils.

v) Pre-Primary School Learning Experiences and Pupils' Achievement in Literacy and Numeracy

The first research question was whether pre-primary school learning experiences predict pupils' early literacy and numeracy achievement. To answer this question, first the researcher determined whether the pupils who participated in the study attended pre-primary school (PP1 and PP2) or not. The results are illustrated in the table below.

\begin{tabular}{|c|c|c|c|c|c|c|}
\hline & $\mathbf{M}$ & $\mathbf{\%}$ & $\mathbf{F}$ & $\mathbf{\%}$ & $\begin{array}{c}\text { T } \\
\text { ot }\end{array}$ & \% \\
\hline $\begin{array}{c}\text { Attended } \\
\text { pre-primary } \\
\text { school }\end{array}$ & 82 & 100 & 68 & 95.2 & 150 & 97.7 \\
\hline $\begin{array}{c}\text { Did not } \\
\text { attend } \\
\text { pre-primary } \\
\text { school }\end{array}$ & 0 & 0 & 4 & 4.8 & 4 & $2.3 \%$ \\
\hline Total & $\mathbf{8 2}$ & $\mathbf{1 0 0}$ & $\mathbf{7 2}$ & $\mathbf{1 0 0}$ & $\mathbf{1 5 4}$ & $\mathbf{1 0 0}$ \\
\hline
\end{tabular}

\section{Attendance of Pre-Primary School}

The above table shows that $100 \%$ of the boys and $95.2 \%$ of the girls attended pre-primary schools. The results show that the majority of the pupils had attended pre-primary schools. Mean scores in literacy and numeracy of the pupils who had attended pre-primary school and those who did not attend pre-primary school were obtained and tabulated. The following table presents the results.

Pre-primary school Experiences and pupils' Literacy and Numeracy scores

\begin{tabular}{|c|c|c|c|c|c|}
\hline & $\begin{array}{l}\text { Sum } \\
\text { of } \\
\text { Squares }\end{array}$ & df & $\begin{array}{c}\pi \\
\text { Square }\end{array}$ & $\mathbf{F}$ & sig. \\
\hline 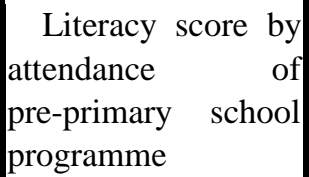 & 309.379 & 1 & 309.379 & 2 & .036 \\
\hline $\begin{array}{l}\text { Numeracy Score } \\
\text { by attendance of } \\
\text { pre-primary school } \\
\text { programme }\end{array}$ & 8.041 & 1 & 8.041 & .022 & .043 \\
\hline
\end{tabular}

\section{ANOVA RESULTS}

The results gives the p-values at .036 for literacy and .043 for numeracy. The p-values in literacy and numeracy were less than 0.05 level of significance therefore it was concluded that there is a statistically significant difference in achievement in literacy and numeracy between pupils with pre- primary school learning experiences and those without. These findings concur with previous studies conducted on the effects of pre-primary school experiences on the pupils' academic achievement outcome where most of the studies agree on the positive effects early learning experiences have on learning outcomes (Hurvitz, 2009; Volante, Villalon\& Muller 2010).

A study by Woldehauna and Gebremedhin (2012), also investigated the effects of pre-primary school on attendance on cognitive development of urban children aged five and eight years in Ethiopia. Results from this study established that pre-primary school attendance had statistically significant positive effect on the cognitive development of children at the ages of both five and eight years, with the bigger impact at latter age. The study further revealed that pre-school attendance has a positive and statically significant effect on primary school enrolment and progression through grades. The findings are consistent with the current study's results that show that pre-primary school learning experiences have a significant predictive value on pupils' literacy and numeracy achievement.

Ampabeng and Tan (2012) also investigated the long-term impact of childhood malnutrition on the cognitive development of famine survivors. Results of the study revealed that negative and significant impact of childhood 


\section{Early Learning Experiences and Teacher-Efficacy As Predictors Of Pupils'Competencies in Early Primary School Grades in Rural Kenya}

malnutrition persisted well into adolescence and adulthood which underscores the importance of quality pre-primary school programmes. Their findings further suggest that the magnitude of the negative experiences in childhood could loom large to latter ages. In line with these results, Osakwe (2009) further established that there was a significant difference in academic performance including cognitive ability, social skills and motor skills between pupils who have pre-primary school education and those without. Most of the studies available on the benefits of pre-primary school learning experiences (Benett, 2008; Hurvitz, 2009 ;). Osakwe, 2009; Volante, Villalon\& Muller 2010) have been conducted outside Kenya. This study was conducted in GuchaDistrict, KisiiCounty Kenya.

\section{vi) Teacher-efficacy and Pupils' Achievement in Literacy andNumeracy}

The second question of this study was; to what extent does teacher-efficacy predict pupils' achievement in literacy and numeracy? To answer this question, overall mean scores in literacy and numeracy of pupils were calculated against teachers' efficacy ratings. The table below presents the results.

\begin{tabular}{|l|l|l|l|}
\hline School & Teachers-efficacy means & Literacy $\boldsymbol{\pi}$ & Numeracy $\boldsymbol{\pi}$ \\
\hline A & 4.50 & 64.70 & 77.60 \\
\hline B & 4.07 & 63.30 & 82.00 \\
\hline C & 3.36 & 62.30 & 70.00 \\
\hline D & 4.57 & 65.90 & 73.00 \\
\hline E & 3.86 & 62.00 & 62.80 \\
\hline F & 3.86 & 58.90 & 63.00 \\
\hline G & 4.29 & 64.80 & 75.60 \\
\hline H & 4.43 & 66.70 & 59.00 \\
\hline
\end{tabular}

\section{Mean scores in literacy and numeracy}

The above table shows teachers' overall self-efficacy ratings and their pupils' overall mean scores in literacy and numeracy for each participating school. The teachers who scored below 3 on the self-efficacy Likert scale were deemed to have low self-efficacy as compared with those who were rated 3 and above. From the above table it is evident that all grade one teachers' demonstrated high sense of self-efficacy score of between 3.36 and 4.57. The results show that the higher the teachers' self-efficacy mean score, the better the pupils' performance scores in literacy and numeracy. To establish whether teachers' self-efficacy was significant predictor of pupils' literacy and numeracy achievement, analysis of variance was run and results are presented in the table below.

\begin{tabular}{|l|c|c|c|}
\hline & $\begin{array}{c}\sum \\
\text { Squares }\end{array}$ & F & p-val \\
\hline Assess pupil's previous knowledge? & 1.042 & 3.4 & 0.01 \\
\hline Involve parents' participation? & 0.042 & 0.1 & 0.06 \\
\hline $\begin{array}{l}\text { Ensure that all pupils are able to read and } \\
\text { write? }\end{array}$ & 0.167 & 0.8 & 0.04 \\
\hline Respond to pupils questions during the lesson? & 2.667 & 4.8 & 0.01 \\
\hline Adjust your lesson? & 0.375 & 0.3 & 0.05 \\
\hline Gauge pupil understanding? & 0.000 & 0.0 & 0.00 \\
\hline Get make pupils perform well? & 0.042 & 0.3 & 0.05 \\
\hline Help pupils to like your subject(s)? & 0.000 & 0.0 & 0.01 \\
\hline Motivate pupils? & 0.167 & 0.8 & 0.04 \\
\hline Encourage group participation? & 3.375 & 13.5 & 0.01 \\
\hline Help pupils who perform poorly? & 0.375 & 0.9 & 0.04 \\
\hline Provide remedial lessons? & 0.042 & 0.0 & 0.04 \\
\hline
\end{tabular}




\begin{tabular}{|l|l|l|l|}
\hline Use a variety of assessment strategies? & 0.042 & 0.1 & 0.01 \\
\hline Encourage parents' participation? & 0.042 & 0.1 & 0.05 \\
\hline
\end{tabular}

\section{ANOVA results and Teachers' Self- Efficacy}

The table above presents computed ANOVA results for teachers' self-efficacy. The results indicate that the p-value in almost all the self- efficacy items for teachers was less or equal to 0.05 . Only teachers' efficacy to involve parents' participation in children's reading and writing was rated at 0.06 . To further establish if there was a significant difference between teachers' overall self-efficacy and pupils' literacy and numeracy achievement, ANOVA was run and the results are presented in table the table below.ANOVA

\begin{tabular}{|l|c|c|c|c|}
\hline Item & df & $\begin{array}{c}\text { Mean } \\
\text { Square }\end{array}$ & F & Sig. \\
\hline Teachers' self- efficacy ${ }^{*}$ pupils 'achievement in literacy & 1 & 131.602 & .168 & .036 \\
\hline Teachers' self- efficacy* pupil's achievement in numeracy & 1 & 377.627 & .504 & .041 \\
\hline
\end{tabular}

From the above table it can be deduced thatthe p-values of 0.036 for literacy and 0.041 for numeracy were less than the acceptable 0.05 level of significance, hence was concluded that there was a significant difference in teachers' self-efficacy and pupils' literacy and numeracy achievement. The results were consistent with previous studies which show a significant difference between teachers' efficacy and pupils' academic achievement (Tella, 2008; Volante, Villalon\&Magadalana, 2010). Tella (2008) also investigated the relationship between teacher self-efficacy, interest, attitude, qualification, experience and pupils' academic achievement in primary school mathematics. A sample of 254 of primary school teachers and 120 primary school pupils was used. The results revealed that teacher-efficacy had significant positive correlation with pupils' achievement scores in mathematics.

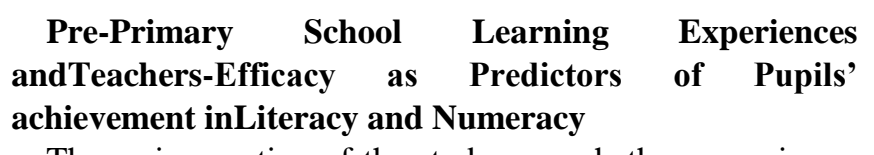

The main question of the study was whether pre-primary school experiences and teacher-efficacy predicts pupils' literacy and numeracy achievement. The computed the results are described below.

\section{Achievement in Literacy and Numeracy}

Computed data clearly that pupils taught by teachers with high self-efficacy, had higher scores in literacy and numeracy than those of taught by teachers with low self-efficacy.Analysis of Variance was run to test the difference and the resultsindicated that the p-value was at 0.000 which is far below the level of confidence $(0.05)$ which shows that pre-school learning experiences and teachers' level of self-efficacy predicts pupils' academic achievement. The results imply that the independent variables contributed significantly to pupils' achievement in literacy and numeracy. The above findings were consistent with previous findings by Tella (2008). He examined the relationship between teacher self-efficacy, interest, attitude, qualification, experience and pupils' academic achievement in primary school mathematics. Results revealed that teacher self -efficacy and interest correlated significantly with the pupils' academic achievement scores. Teachers' self-efficacy was found to be the best predictor of pupils' academic achievement in mathematics followed by teachers' interest. The current study reveals that pre-primary school learning experiences and teacher-efficacy levels together significantly predicts pupils' academic achievement.

\section{CONCLUSIONS}

The aim of the study was to establish whether

Pre-primary school learning experiences predicted learners' achievement in literacy and numeracy competencies.

It emerged that pupils who had attended pre-primary school posted higher scores in both numeracy and literacy compared with those who did not or partially attend pre-primary school. Therefore it was concluded that there was a significant difference in literacy and numeracy achievement between pupils with pre- primary school learning experiences and those without.

It was further established that the higher the teachers' self-efficacy mean score, the better the pupils' achievement scores in literacy and numeracy. Hence it was concluded that there was a significant difference in teachers' self-efficacy and pupils' literacy and numeracy achievement.

Both pre-primary school early learning experiences and teachers' self-efficacy significantly predicated pupils' learning competence achievement. This therefore means that that pre-school learning experiences and teachers' level of self-efficacy could greatly enhance learning outcomes in early grades.

\section{RESEARCH RECOMMENDATIONS}

Based on the above findings the researchers made the following recommendations to specific stakeholders in a bid to promote competencies across domains among early grade learners.

- The ministry of education science and technology (MoEST) to make pre-school compulsory and accessible to all pupils before joining primary lower grades. This may be possible particularly if the State funded the sector well to meet the necessary resources for effective learning.

- Government to mobilize Parents and community as a whole to appreciate the role played by early learning 


\section{Early Learning Experiences and Teacher-Efficacy As Predictors Of Pupils'Competencies in Early Primary School Grades in Rural Kenya}

centers in building capacity to learn among learners. Parents should support and manage early childhood programmes for holistic development of the children.

- Ministry to enhance teachers' self-efficacy by organizing refresher courses for lower primary grades in order to promote their ability to support promote learning and smooth transition from lower grades to upper grades.

\section{REFERENCES}

[1] Ampaabeng, K., \&Tan,M.C.(2012). The long-term cognitive Consequences of Early Childhood Malnutrition: The Case of Famine in Ghana. Worcester. Clark University.

[2] Anderson, R., Greene, M., \&Loewen, P. (1988). Relationships among teachers' and students' thinking skills, sense of efficacy, and student achievement. Alberta Journal of Educational Research, 34(2),

[3] Barnett, W.S. (1995). Long-term effects of early childhood programs on cognitive and social outcomes. The future of children. Journa 5(3):

[4] Barnett,S.W. (2008). Pre-school education and its Lasting Effects: Research and Policy Implications. National Institute for Early Education Research. Rutgers, the State University of New Jersey.

[5] Best, J.W (1992). Research in education. New Jersey: Prentice Hall.

[6] Bronfenbrenner, U. (1979). The Ecology of Human Development: Experiments by Nature and design. Cambridge, MA: HarvardUniversity Press.

[7] Chege F. N., Likoye, F., Nyambura, S. \&Guantai H. K (2013). Declining Boys' participation and performance in Kenyan Schools: are girls 'education projects influencing new forms of masculinities. Kenyatta University. Journal. Retrieved June $12 \quad 2014$ from: http://home.hiroshima-u.ac.jp/cice/wp

[8] COAG, (2009). Investing in the early years- a National Early Childhood Development Strategy. Canberra: Commonwealth of Australia. Retrieved on $11^{\text {th }}$ Dec 2013: From http: www.coag.gov.au/node/205.

[9] COAG,(2008). National Numeracy Review Report. Retrieved on $16^{\text {th }}$ June 2014 from: http:www.curriculum.edu.au/.

[10] Fabian, H. (2007). Empowering children for transitions. London: Routledge.

[11] Felner, R.D., Jackson, A.W., Kasak, D., Mulhall, P., Brand, S., \& Flowers, N. (1997). The impact of school reform for the middle years: Longitudinal study of a network engaged in Turning Pointsbased comprehensive school transformation. Kappan.

[12] Goddard R., Hoy K., \&Woolfolk, A., 2011). Collective teacher efficacy: Retrieved on $29^{\text {th }}$ Mar 2012 from; http://www.google.co.ke

[13] Green, A.D., Riddle, C. W.(2012). Understanding Educational Impacts: The role of Literacy and Numeracy Skills. Columbia. University of British Columbia.Department of Economics.

[14] Grossman, B. (1997). Effectiveness of A Pre-first Grade Program on later academic achievement. Unpublished M.Ed. Thesis. Rochester Institute of Technology. Indonesia.

[15] Guo,Y., Piasta, S.B., Justice, L.M \&Kadearavek, J.N. (2010). Relations among Pre-school teachers' self-efficacy, classroom Quality, and Children's language and Literacy gains: Teaching and teacher education. Journal, 26, 1094.

[16] Harrison, J.L. Goldfield, S., Metcalfe, E \& Moore, T. (2002). Closing the gap: Early learning programmes that promote children'sdevelopment and Educational Outcomes. Closing Gap. Clearinghouse: Australian Government, Australian Institute of Health and Welfare \& Australian Institute of Family Studies.

[17] Kail,R.V., \& Cavanaugh, J.C. (2010). The study of Human Development. Human Development; A Life-Span View ( $5^{\text {th }}$ Ed.). Belmont, CA: Wadsworth Cengage learning.

[18] Kiptum J. K., Rono P K., Too, J K., Bii B K., \& TOO J (2013). Effects ofStudents Gender onMathematics Performance in Primary Schoolsin Keiyo south District, Kenya: International journal of scientific \& technology research volume 2, issue 6, June 2013ISSN 2277-8616 -247 ijstr@2013 www.ijstr.org. Retrieved on June 13, 2014 from: http://citeseerx.ist.psu.edu/viewdoc/summary.

[19] Kothari,C.R.(2004). Research Methodology; Methods \&techniques. New Delhi. New Age International (P) Ltd.
[20] Marcon, R. (1992). Differential effects of three preschool models on inner-city 4-year- olds. Early Childhood Research Quarterly, 7(4): 517-530. Retrieved on $17^{\text {th }}$ march 2012 from: rmarcon@unf.edu

[21] Marcon, R. (1999). Early learning and early identification: Final report of the three year longitudinal study. Washington, DC: District of Columbia Public Schools. Retrieved on $17^{\text {th }}$ march 2012 from: ttp://www.guardian.co.uk/education.

[22] MoE, (2006). Strategic Plan 2006-2011. Nairobi: Republic of Kenya.

[23] MoE, (2008). Handbook for early childhood development education syllabus. Nairobi. KIE.

[24] MoEST, (2008). Final Report on the Kenya Education Management Capacity Assessment (KEMACA). Nairobi. Government Press.

[25] Mwoma, T. Limboro, C. \&Mugo, J. (2013). Who is teaching our children? Prime Journal. Retrieved on March $21^{\text {st }} 2014$ from

[26] Oduor, A (2017): Why candidates fail in National examinations in Kenya. Article available at; https://bit.ly/2u

[27] Orodho J, O. (2009). Research methodology. Nairobi: Masola.

[28] Osakwe, R.N. (2009). The effects of Early Childhood Education Experience on the academicPerformance of Primary School Children. Delta State University. Nigeria.

[29] Ouko, H.O, (2015); Determinants of pre-primary school children's achievement in Literacy and Numeracy in Gucha-Kisii County, Kenya. Unpublished Thesis. Kenyatta University. Nairobi.

[30] Randerson (2008). Long-term benefits of pre-school learning. Retrieved on $10^{\text {th }}$ April 2014 from:http://www.google.co.ke

[31] Richardson, E.G. (2011).Teacher Efficacy and its effects on the Academic achievement of African American students. $\mathrm{PhD}$ Dissertation. GreenLeaf University district, Kenya.

[32] Santrock, J.W. (2007). A Topical Approach to Life-span Development.

[33] Taiwo, A.A., \&Tyolo, J.B. (2002). The effects of Pre-primary School Education on Academic Performance in Primary School: A case study of grade one pupils in Botswana. University of Botswana

[34] Tella, A. (2008). Teacher Variables as Predictors of Academic Achievement of Primary school pupils' mathematics. Osun State University: International Electronic Journal of Elementary Education Vol.1 Oct.2008.

[35] UNESCO, (2005). Early Childhood Policy Review Project: The Background Report of Kenya. MoEST.

[36] UNESCO, (2005). The Unesco/Oecd Early Childhood Policy Review Project Report. Nairobi. UNESCO

[37] UNICEF, (2005; 2007). Early Childhood development. Nairobi. Eastern and Southern Africa Regional Office.

[38] UWEZO, (2011). East Africa report of July $4^{\text {th }}$ 2011. Retrieved on $27^{\text {th }}$ march 2012 from: http:/vijana.fm/ 2011/07/04eat-Africa report.

[39] Volante, P., Villalon, M. \&Magadalena, M. (2010). Teacher efficacy beliefs and Students academic Performance for High vulnerable Areas.ICSEI. No.Faculty of Education Journal. Chile.

[40] Woldehauna, T., \& Gebremedhin, L.(2012). The effects of pre-school attendance on the cognitive development of urban children aged 5 and 8 years: Evidence from Ethiopia. Young Lives; An international study of childhood poverty. Retrieved on $9^{\text {th }}$ June 2014 from: www.younglives. org.uk.

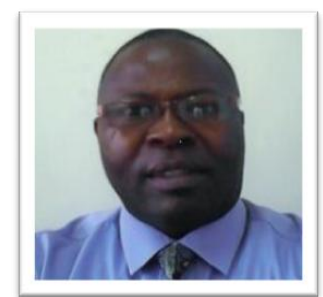

Ong'ang'a H.M Ouko (Ph.D)

The author is a lecturer at the department of early childhood studies and special needs Education, Kenyatta University, Kenya. He has a $\mathrm{Ph} . \mathrm{D}$. and a master of education (Early childhood Studies) degrees from Kenyatta University. He has a lot of experience in teacher- training teachers and research in child and family studies. His experience is mainly on teacher training and research in early years' education. He has done a number of training modules for training in the area of early childhood studies. He has published in a number of journals. The author is a consultant in early years' curriculum design and development, children's rights advocacy, community education and development, research in family and child studies among other aspects involving young children. Currently he is a founder member of the National ECD Network Kenya. 